\title{
Beyond "Methodological Islamism”? A Thematic Discussion of Muslim Minorities in Europe
}

\author{
Nasar Meer ${ }^{1}$, Tariq Modood ${ }^{2}$ \\ ${ }^{1}$ Centre for Civil Society and Citizenship, Northumbria University, Newcastle, UK \\ ${ }^{2}$ Centre for the Study of Ethnicity and Citizenship, Bristol University, Bristol, UK \\ Email: nasar.meer@unn.ac.uk
}

Received June $24^{\text {th }}, 2013$; revised July $24^{\text {th }}$, 2013; accepted July $31^{\text {st }}, 2013$

Copyright (C) 2013 Nasar Meer, Tariq Modood. This is an open access article distributed under the Creative Commons Attribution License, which permits unrestricted use, distribution, and reproduction in any medium, provided the original work is properly cited.

\begin{abstract}
In this discussion we offer an overview of the place of Muslim actors in European scholarship. We especially focus on the second and subsequent generations of European Muslims, and how future research agendas could conceptualise the relationship between contemporary Muslim identity and citizenship regimes in Europe. We explore the way in which our understanding is formed by a concern with socioeconomic processes, cultural adaptations and civic status. We include questions of citizenship and "difference”, and the extent to which there has been a re-imagining and re-forming of national collectivities in the face of Muslim claims-making. By claims-making we invoke a further register which centres on the creation of a Muslim infrastructure, perhaps through modes of religious pluralism (or opposition to it), and how this interacts with prevailing ideas that to greater and lesser extents inform public policies e.g., multiculturalism, interculturalism, cohesion, secularism, or Leitkulture, amongst others. While the latter register focuses more on nation-state politics, there is a further transnational dimension in the Muslim experience in Europe, and this assumes an important trajectory in the ways discussed. It is argued that Muslim identities in Europe contain many social layers that are often independent of scriptural texts; such that the appellation of "Muslim" can be appropriated without any unanimity on Islamic matters. We conclude by observing how this point is understudied, and as a consequence the dynamic features of Muslims' leadership in Europe remain unexplored.
\end{abstract}

Keywords: Islam; Europe; Citizenship; Muslim Identity; Integration; Claims-Making

\section{Introduction}

Estimations on the number of Muslims in Europe range between fifteen and twenty millions (cf; Maussen, 2007: 4; Pew, 2010: 5; Hunter, 2010: 16). When we include historically established Muslims, of the Balkans, Mediterranean and indeed of the former Eastern bloc (e.g., Tartars in Poland), it has been said that Muslims are more numerous than Catholics in the traditionally Protestant north of Europe, and more numerous than Protestants in the traditionally Catholic south (Klausen, 2005). Over the last three decades social scientists have increasingly sought to establish an evidence base from which to conceptualise and chart the sociological and political features of this large scale post-war presence in European societies (Etienne, 1989; Neilsen, 1992, 1999; Lewis \& Schnapper, 1994; AlSayyad \& Castells, 1997; Chapman, 1998; Zolberg \& Loon, 1999; Koopmans \& Statham, 1999; Body-Gendrot \& Martinello, 2000; Mandaville, 2001; Cesari, 2004; Koopmans et al., 2005; Klausen, 2005; Bowen, 2006; Lawrence \& Vaisse, 2006; Modood, Tryandifillidou, \& Zapata-Barrero, 2006; Bader, 2007; Modood, 2007; Jacobs \& Rea, 2007; Simon \& Piché, 2012; Bleich, 2009; Levey \& Modood, 2009; Triandafyllidou, 2010; Gest, 2010; Meer, 2010, 2012, 2013; Faas, 2010; Mouritsen, 2013). This body of research has traversed both cultural and structural features e.g., the dynamics of Muslim ethno-religious values and cultural adaptations (see below), as well as Muslim participation in labour markets and educational outcomes. For example, with regard to the latter issue, cross-national research is beginning to support more local (national) studies in findings that across Europe Muslims are more likely to be consistently socio-economically disadvantaged than other groups (with the exception of Roma and traveller communities), evidenced in higher levels of unemployment and lower levels of income (and more likely to be employed in unskilled work) (Open Society Institute (OSI), 2010: 96).

To focus on socio-economic issues alone would offer a limited account, for we may more broadly disaggregate at least four frames through which to conceptualise the status of Muslims in Europe. Each is concerned with socio-economic processes, cultural adaptations and civic status but the first explores the process of near recent immigration itself. The obvious shortcoming with this focus is that the majority of Muslims in Europe are not migrants but Europeans with migrant parentage (whether or not they would be recognised as such by their fellow European citizens). This observation points to a second frame concerning questions of citizenship and "difference", and the extent to which there has been a re-imagining and re-forming of national collectivities in the face of Muslim claims-making. By claims-making we invoke a third register which centres on the creation of a Muslim infrastructure, perhaps through 
modes of religious pluralism (or opposition to it), and how this interacts with prevailing ideas that to greater and lesser extents inform public policies e.g., multiculturalism, interculturalism, cohesion, secularism, or Leitkulture, amongst others. While the latter register focuses more on nation-state politics, there is a fourth transnational dimension in the Muslim experience in Europe, and this assumes an important trajectory in the ways discussed below. In forging a comprehendible path through a field as vast as this, it is inevitable therefore that we offer a partial account that does not seek to reprise all debates. That would be impossible in the permitted space. There are collections that are able to present a more comprehensive view that we would encourage readers to consult (e.g., Triandyfillidou, Modood, \& Meer, 2011; Modood, Triandifilidou, \& Zapata-Barrero, 2006). In this discussion, we are specifically interested in the second and subsequent generations of European Muslims, and how future research agendas should be conceptualising the relationship between contemporary Muslim identity and citizenship regimes in Europe. Nonetheless, before we turn to this we would like to discuss some of the dynamics of migration which continue to have a bearing in current debates about citizenship. After this we move on to discuss some of the pressing questions in conceptualising Muslim identities, before ending with an account of the possibilities of citizenship for Muslims in the $21^{\text {st }}$ century Europe.

\section{From Migrants to Citizens}

The focus of this article are the Muslim communities forged through post war migrations from Turkey, north and sub-Saharan Africa, and South Asia, who mainly settled in the urban centres of formerly colonial and/or labour recruiting countries in northern, western and, latterly, southern Europe. In the three largest European states, there are approximately three million Muslims in the Britain, three and a half million in France and over four million in Germany (see Table 1). The motivations for these migrations are mixed, as are their reception in different states. This can be illustrated by contrasting post-war movement to Germany from Turkey, and movement to Britain from Pakistan (and later Bangladesh). Both were an outcome of pull factors in so far as demand for unskilled labour in each economy drew in migrants (as opposed to France where there were additional "push" factors of civil war in their former colony of Algeria). Family re-unification and community formation came later. But in each case the status they encountered as migrants differed. Some studies frame this is terms of diverging modes of integration (or indeed non-integration) that function as path dependencies. For example, Soysal's (1994) account of "regimes of incorporation" sub-divides into those that she conceives as corporatist (e.g., Sweden and Netherlands), individualist (e.g., Switzerland and UK), state-centralized (France), and statist-corporatist (Germany), respectively. Koopmans et al., (2005) come to the same task through an "institutional opportunity structures" approach, and produce four conceptions of citizenship as: 1) ethnic assimilationism (e.g., Germany, Switzerland), 2) ethnic segrationalism, 3) Civic republicanism (France; and the UK), and 4) civic pluralism (Netherlands). In Koopmans et al. (2005: 73), this model is applied to the position of five countries (as shown above) at three moments in time (1980, 1990 and 2002), and finds that two important movements occurred between 1980 and 2002. The first was a movement to
Table 1.

The number of Muslims in Europe. (Taken from the Pew Research Center's Forum on Religion \& Public Life • Forthcoming Pew Forum Report, 2010).

\begin{tabular}{|c|c|c|}
\hline Country & $\begin{array}{c}\text { Estimated } 2010 \\
\text { Muslim Population }\end{array}$ & $\begin{array}{c}\text { Percentage of Population } \\
\text { That Is Muslim }\end{array}$ \\
\hline Austria & 475,000 & 5.7 \\
\hline Belgium & 638,000 & 6.0 \\
\hline Denmark & 226,000 & 4.1 \\
\hline Finland & 42,000 & 0.8 \\
\hline France & $3,574,000$ & 5.7 \\
\hline Germany & $4,119,000$ & 5.0 \\
\hline Greece & 527,000 & 4.7 \\
\hline Ireland & 43,000 & 0.9 \\
\hline Italy & $1,583,000$ & 2.6 \\
\hline Luxembourg & 13,000 & 2.7 \\
\hline Netherlands & 914,000 & 5.5 \\
\hline Norway & 144,000 & 3.0 \\
\hline Portugal & 22,000 & 0.2 \\
\hline Spain & $1,021,000$ & 2.3 \\
\hline Sweden & 451,000 & 4.9 \\
\hline Switzerland & 433,000 & 5.7 \\
\hline United Kingdom & $2,869,000$ & 4.6 \\
\hline Total & $17,094,000$ & \\
\hline
\end{tabular}

wards cultural pluralism in all five countries, though to differing degrees and from quite different starting points, and the second was a movement towards civic conceptions of citizenship. Other social scientists have illuminated the contingent ways in which European states have developed specific modes of dealing with religious difference. Brubaker (1992) takes in fewer countries to offer a historical sociology of the transformations within France and Germany of ideas (propagated amongst nation-builders) that their nation conferred a citizenship that resembled ius soli or ius sanguinis respectively. Favell's (1998) discussion of "philosophies of integration" developed a context sensitive comparative politics, emphasising the role of "public philosophies" in facilitating the kinds of citizenship that will prevail in different national contexts.

For example, in Germany, migrant workers were recruited as "guest workers" (Gastarbeiter) on the assumption that they would not remain after the tenure of their employment. Muslims thus encountered a polity where citizenship and nationhood were heavily anchored in the idea of an ethnically homogenous majority. In this context, the naturalisation of Turkish Muslim "foreigners” (Ausländer) was discouraged and limited, and only migrants with German ethnicity (Aussiedler) were fully admitted. Following decades of pursuing an ethnonational citizenship Germany has since the late 1990s undergone significant changes in the management of immigration, integration and its concept of citizenship. Where federal policies had pre- 
viously focused almost entirely on the control and return of migrants (Schönwälder 2001), the Citizenship Law (2000) introduced the principle of ius soli. This led to a slew of new legislation such as the Immigration Law (2005), which is geared toward integration strategies, and the invitation to migrants and civil society actors to take part in a National Integration Summit (2006). Each of these is said to comprise "milestones" in that they speak with Muslim migrant minorities and not solely about them. The amendment to the Citizenship Law (2000) means that the children of "foreigners" now automatically acquire German citizenship if one parent has been legally residing in Germany for at least eight years with a "right to abode” permit. These children can retain dual nationality until the age of twenty-three, after which they have to choose between German citizenship and the citizenship of their parents. One outcome of this policy is that when thousands of Turkish migrants applied for the reissuing of their Turkish passports in 2001 after having been naturalised, German authorities responded by withdrawing their German nationality and residence permits. The fact that the right to vote on the municipal level is only valid for EU nationals and that there is no parliamentary will to afford the franchise to Third Country Nationals (TCNs) disproportionate ly affects German Turkish nationals. So while the German developments have marked important shifts, they have not overcome the issue of dual nationality nor entirely decoupled citizenship from an ethnic project, legally, let alone in terms of social attitudes.

Germany's staggered approach is to be contrasted with the different set of issues raised in Britain. There, post-war Muslim migrants from the Indian subcontinent arrived as Citizens of the United Kingdom and Commonwealth (CUKC), and their subsequent British-born generations were recognised as ethnic minorities requiring state support and differential treatment to overcome distinctive barriers in their exercise of citizenship. Although lacking an official "Multicultural Act" or "Charter" in the way of Australia or Canada (CMEB, 2000), Britain rejected the idea of "returnism" or of integration being based upon a drive for unity through an uncompromising cultural "assimilation”. It did so when the Labour home secretary Roy Jenkins (1966) defined integration as "not a flattening process of assimilation but equal opportunity accompanied by cultural diversity in an atmosphere of mutual tolerance". The debates that have occurred in Britain therefore have had much less to do with residence rights and a great deal more to do with cultural recognition (though family reunification has been an important issue). For example, Muslim concerns over the limitations of a colour based race equality were brought to the fore during the experiences of the Rushdie Affair (Modood, 1994). Here a publication of a novel that disparaged both the genesis of Islam and the biography of the Prophet Mohammed gave rise to a great deal of hurt and anger amongst Muslims who felt that "as citizens they [were no less] entitled to equality of treatment and respect for their customs and religion" (Anwar, 1992: 9) than either the Christian majority denominations and other religious minorities. In this context, the issues raised were much wider than the complaint of blasphemy (an offense that was recently eliminated without opposition from Muslims), for the Muslim protest was expressed as a new ethno-religious challenge to "exclusion from the existing equality framework" (Modood, 2009: 485).

The important point to take from this brief contrast is that national models are not helpful when seen as fixed. Instead the context of Muslim-state engagement should be viewed as dynamic. Indeed, as Bowen (2007) argues "national models themselves are historical products, and as such inevitably contain within them multiple lines of reasoning and emotion, developed in counterpoint to each other" (ibid.), something that can lead to "paradoxes and unintended consequences even when they succeed in remain logically consistent” (ibid. 1006).

\section{Muslim Transnationalism(s)}

One issue that further complicates where Muslims fit into national models concerns the status of Muslim identity as a transnational force. Here it is common that discussion of Islam and transnationalism in Europe centres on the concept of the umma (the global imagined community of Muslims). This is certainly one expression of Muslim transnationalism, and Mandaville (2009) sets it in the context of four prevailing-and often overlapping - forms that take us beyond a literal reading of what this is alleged to entail. Indeed, and instead of focusing on the religious framings, Mandaville provides a useful discussion of some core social and political expressions of Muslim transnationalisms. The first concerns Muslim "people flows” in so far as the physical movement of Muslims to Europe has created "an infrastructure of conduits and networks through which other forms of Muslim transnationalism can flow” (ibid. 494). This is a direct outcome of significant Muslim settlement and community formation. The second is expressed in organised social and political movements "whose agendas and organisational structures transcend nation-state boundaries (although some of them, importantly, operate at the behest, or with the financial support, of state authorities)" (ibid. 494-5). While this may be organised in some sense, it is highly dispersed across social fields and political landscapes. The third prevailing form relates to the creation of transnational public spheres, "enabled by the proliferation of new media and information and communication technologies” (ibid. 495). This is a highly dynamic development and might be one illustration of Fraser's (1992) "subaltern-counterpublics" in which Muslim media sources "represent an expanding social field characterized by more than contested authority and by more than proliferating voices or blurred boundaries; central to this expanding public sphere of Islam are new media and interest profiles they advance" (Anderson, 2003: 888). Each of these three prevailing forms of Muslim transationalism might, moreover, be connected to Beck's (1998: 29) reading of "a new dialectic of global and local questions”. Perhaps not immediately apparent to Beck, we might here also include transnational Islamist politics. One thinks here of Islamist movements that have traveled outwards, and been relocated, from their provenance in the Muslim Brotherhood (MB) from Egypt in 1928, or Jamat-e-Islami from northern India of the 1930s. The point with either example is that there is some semblance of a framework in which the public sphere is globalised and participatory. The implications of this are brought out in Mandaville's (2001: 46) assessment that we can "think of transnationalism as possessing certain emancipatory qualities which allow us to move towards a political imagination beyond the categories of the territorial state". This would appear to be at least $a$ cornerstone of political Islam, and the discussion more broadly is valuable in pointing to the factors we should take into consideration in conceptualizing the contemporary Muslim presence in Europe.

Yet it is one part of a story that and so is by no means the best way of considering how the identity category of "Muslim" 
has become a vehicle for political participation and citizenship that is very much centered on the nation-state (as discussed below). If it has become a vehicle for participation within nation states, it is also related to understanding how discrimination against Muslims has proliferated. Indeed, Islamophobia and anti-Muslim sentiment are profound and deeply ingrained problems that Muslims in Europe constantly negotiate (Meer, 2013). European-wide Pew (PGAP, 2008) data, for example, reports that opinions of Muslims in almost all of the twentyfour countries surveyed were more negative, with more than half of Spaniards and half of Germans stating that they did not like Muslims, while the figures for Poland and France were 46 per cent and 38 per cent for those holding unfavourable opinions of Muslims. Interestingly, while Americans and Britons displayed the lowest levels of Antisemitism, one in four in both countries was hostile to Muslims. This means that in the USA, France and Germany unfavourable views of Muslims are roughly at twice the rate of unfavourable views of Jews, while in Poland and Spain the former are only a few percentage points more. While quantitative surveys do not always provide the best accounts of prejudice and discrimination, they can be useful in discerning trends alerting us in this case to the widespread prevalence of an anti-Muslim feeling. In the last British Attitudes Survey, for example, Voas and Ling (2010, pp. 80-81) report that one fifth of the total population responds negatively only to Muslims, and that relatively few people feel unfavourable towards any other religious or ethnic group on its own. Across Europe meanwhile, Zick, Kupper and Hovermann (2011, pp. 62 3) too conclude:

"[I]t is conspicuous that Europeans are largely united in their rejection of Muslims and Islam. The significantly most widespread anti-Muslim attitudes are found in Germany, Hungary, Italy and Poland, closely followed by France, Great Britain and the Netherlands. The extent of anti-Muslim attitudes is least in Portugal. In absolute terms, however, the eight countries [Britain, France, Netherlands, Germany, Italy, Poland, Portugal and Hungary] differ little in their levels of prejudice towards Muslims".

The visibility of Muslims, especially of the display of what are sometimes termed contested signifier in terms of dress and appearance, is frequently the means through which this Islamophobic feeling is turned into Islamophobic behaviour (Meer, Dwyer and Modood 2010). A good European-wide illustration may be found in the summary report on Islamophobia published by the European Monitoring Centre on Racism and Xenophobia shortly after 9/11. This identified a rise in the number of "physical and verbal threats being made, particularly to those visually identifiable as Muslims, in particular women wearing the hijab" (Allen and Nielsen 2002, p. 16). What is of particular note is that despite variations in the number and correlation of physical and verbal threats directed at Muslim populations among the individual nation states, one overarching feature that emerged among the fifteen EU countries was the tendency for Muslim women to be attacked because of how the hijab signifies an Islamic identity (Allen \& Nielsen, 2002: p. 35). Yet if Islamophobia is a prevailing current, this has not prevented Muslims from innovating with Islam in European contexts, not least through debates about EuroIslam.

\section{Euro-Islam as a Multidirectional Process}

Euro-Islam is a relatively recent addition to the repertoire of concepts describing the possibilities for Islam in Europe that Muslim migrants and subsequent generation's herald (see Meer, 2012; Yildiz \& Verkuyten, 2012). Beyond this there is little consensus amongst its main theoreticians. For the Swiss born philosopher Tariq Ramadan (2004: 4), Euro-Islam describes a process that is already underway, in which "more and more young people and intellectuals are actively looking for a way to live in harmony with their faith, participating in the societies that are their societies, whether they like it or not". Ramadan describes this as the cultivation of a "Muslim personality", one that is "faithful to the principles of Islam, dressed in European and American cultures, and definitively rooted in Western societies.” (2004: 4). He continues:

"While our fellow-citizens speak of this 'integration' of Muslims 'among us', the question for the Muslims presents itself differently: their universal principles teach them that wherever the law respects their integrity and their freedom of worship, they are at home and must consider the attainments of these societies as their own and must involve themselves, with their fellow-citizens, in making it good and better" (ibid: 5).

Ramadan is thus prioritizing a scriptural inheritance that needs to be reconciled with current and future lived practice, in a manner that reflects " $a$ testimony based on faith, spirituality, values, a sense of where boundaries lie", something that "reverses the perception based on the old concepts" (2004: 73). This reasoning leads to an interesting juxtaposition in that " $M u$ slims may feel safer in the West, as far as the free exercise of their religion is concerned, than in so called Muslim countries" (2004: 65). The implication of this position is that the dichotomy between the two "abodes" can no longer be sustained. The resolution to this, Ramadan suggests, rests in an exercise of critical interrogation in which European Muslims: have no choice but to go back to the beginning and study their points of reference in order to delineate and distinguish what, in their religion, is unchangeable (thabit) from what is subject to change (mutaghayyir), and to measure, from the inside, what they have achieved and what they have lost by being in the West (2004: 9).

Ramadan's project might then be characterized as both classicist and revisionist in that he stakes out an ethical resource in Islamic scriptures to propose a qualitatively novel solution that is calibrated to contemporary-traditionally non-Muslim majority-societies. Yet it is precisely this project of reconciliation between Islamic doctrines and European conventions that is challenged by Bassam Tibi (2008: 177), the other key exponent of "Euro-Islam". For if Europe is no longer perceived as dar $a l$-harb, and instead considered to be part of the peaceful house of Islam, he maintains, "then this is not a sign of moderation, as some wrongly assume: it is the mindset of an Islamization of Europe". He continues:

"In defense of the open society and of its principles, it needs to be spoken out candidly: Europe is not dar al-Islam (or, in the cover language of some, dar al-shahada), i.e. it is not an Islamic space but a civilisation of its own, albeit an exclusive one that is open to others, including Muslims. These are, however, expected to become Europeans if they want to be part of Europe as their new home.” (2004: 159)

In Tibi's view, the burden of adaptation required to cultivate a Euro-Islam must rest heavier with Muslims than amongst the institutions and conventions that constitute European societies. That is to say that a civilizational notion of Europe, one that he traces back to the age of Carolingians, must be the vessel in 
which Islam in Europe comes to rest. Tibi's formulation is principally driven by an anxiety over the disproportionate development of sizable Muslim communities in Europe, and the concomitant emergence of a Muslim consciousness (or in Ramadan's terms “Muslim personality”). This leads Tibi (2008: 180) to insist that without doctrinal reforms in Islam, that is: "without a clear abandoning of concepts such as da'wa, hijra and shari'a, as well as jihad", there can be no Europeanization of Islam. One source of Tibi's dualism centres on the re- lationship between religious doctrine and migration, especially with regards to the status on proselytization, meaning that "if da'wa [prayer] and hijra [migration] combined continue to be at work; the envisioned 'Islamization of Europe' will be the result in the long run" (2008: 177). This can only be averted in Tibi's view if Muslims acknowledge that the identity of Europe is not Islamic. The direction of travel here, that is to say that the focus on what needs to be revised, marks the key distinction here between Ramadan and Tibi. Hence the latter has elsewhere promoted the need for a European Leitkultur - a guiding culture or leading culture-characterized by values of "modernity: democracy, secularism, the Enlightenment, human rights and civil society" (Tibi, 1998: 154). Of course how the concept of Leitkultur has been adopted varies profoundly and may in many instances not be endorsed by TIbi himself, but in both origin and adoption Tibi makes a regressive argument that assumes that the insistence on assimilation is both Just and a plausible policy option, neither of which we consider to be the case (Meer, 2012).

Despite their differences, both accounts offer an interpretation of the Muslim subject that is theologically grounded but socially iterative. That is to say that while differing profoundly in important respects, both Ramadan and Tibi anchor the development of a Muslim consciousness in Europe to a doctrinal innovation in Islam. Perhaps both authors therefore offer too linear a relationship between Islamic doctrine and Muslim identity in a way that minimizes the role of the social. The implication being that-no less than with any text-Islamic scriptures offer guidance that are interpreted and applied by human agents in particular social contexts. As Omid Safi (2004: 22) reminds us: "in all cases, the dissemination of the Divine teachings is achieved through human agency. Religion is always mediated." The point is that the meaning of a text has to be understood in terms of not just interpretations but social context. Through such an approach we would be relocating the "Muslim subject" in society and amongst Muslim populations.

\section{Beyond "Methodological Islamism”?}

Despite the routine discussion of Muslims in Europe as Muslims, however, the appellation remains the focus of much debate. While Bleich (2009: 364) is surely correct in observing that the salience of "Muslim" certainly reflects how "Islam has become an identity consciously deployed by a significant percentage of Muslims", this reading is problematised by others. Brubaker (2012: 5), for example, argues that scholars have been guilty of a conflation between categories of analysis and categories of practice. By this he means researchers have not stood "outside the process through which postulations of immigrant origin have been transformed into Muslims. They have not simply registered this shift; they have contributed to producing it, as scholarly literature on Muslims has proliferated" (ibid). He continues:

“Identifying one's object of analysis as 'Muslims', for exam- ple, highlights religious affiliation and, at least implicitly, religiosity; it also marks the population of interest as different from the surrounding both religion and religiosity... Muslims in Europe are indeed deeply and multiply disadvantaged; but they are not disadvantaged, in the first instance as Muslims" (ibid.).

Brubaker makes a cautionary intervention, but it is one that needs to be set against more complicated research narrative. This begins by registering an initial sociological question which asked why, for example, an attachment to Islam was not relinquished, as secularization theories predicted, during the process of migration, post-migration settlement, or indeed with subsequent socialisation in relatively secular societies (Neilson, 1984). One explanation was that an attachment to Islam provides resources, refuge and respect during migration and resettlement (Modood, 1988; Werbner, 1994; Meer, 2010, cf Hirschman, 2004). Hence the Fourth National Survey of Ethnic Minorities (Modood et al., 1997) identified the tendency for an overarching "associational identification" with Islam which reoccurs across first and second generation Muslims. This does not mean that self-identification as "Muslim" in Europe has not permitted different kinds of hybridity (e.g., as "British-Muslim”), or unchanging (e.g., reflecting a different meaning to young Muslims born and brought up in Marseille to that of their parents who migrated from Morocco); nor does it mean that self-identification as Muslim in Europe has been anchored in a subscription to a single Islamic doctrine (Roy, 2004). Indeed, the precise meaning of "Muslim" has instead taken on a number of competing public forms, some of which have most recently been accentuated in concerns about violent extremism (O’Toole et al., 2013). This illustrates that researchers have not been as guilty of a mono-causal reductionism as Brubaker holds. For the term "Muslim" has not appeared through a Gestalt like switch, and those who use it do not limit it to one or other narrow meaning (nor new possibilities for its meaning). This is summarised by Modood (2007: 134) "For some Muslims... being Muslim is a matter of community membership and heritage; for others it is a few simple precepts about self, compassion, justice and the afterlife; for some others it is a worldwide movement armed with a counter-ideology of modernity; and so on. Some Muslims are devout but apolitical; some are political but do not see their politics as being "Islamic" (indeed, may even be anti-“Islamic"). Some identify more with a nationality of origin, such as Turkish; others with the nationality of settlement and perhaps citizenship, such as French.” Rather than foreclose them, this reading opens up further lines of research in seeking to ascertain a valid account of the contemporary Muslim experience in Europe. As Meer (2012: 189) describes:

"[T]he relationship between Islam and a Muslim identity might be better conceived as instructive but not determining, something analogous to the relationship between the categorization of one's sex and one's gendered identity. That is to say, one may be biologically female or male in a narrow sense of the definition, but one may be a woman or man in multiple, overlapping and discontinuous ways-one's gender reflects something that emerges on a continuum that can be either (or both) internally defined or externally ascribed."

Compared to the purely theological variety, this sociological category might be preferred as a less exclusive way of operationalizing Muslim identity because it includes opportunities for self-definition (such as formally on the census or on "ethnic" monitoring forms or informally in public and media dis- 
course). Equally, it can facilitate the description of oneself as "Muslim" and take the multiple (overlapping or synthesized) and subjective elements into account independently of or intertwined with objective behavioural congruence with the religious practices. It is maintained that this space for self-definition is a helpful means of conceptualizing the difference with externally imposed Muslim and Islamic identities, with both (internal and external) potentially becoming more prominent at some times and less at others.

\section{Engaged Muslim Citizenship: An Agenda for Inquiry}

One area where this may be observed is in Muslims-state participation, sometimes described as governance, in forging types of participatory citizenship. As Meer (2010; 2012) hypothesises, Muslim identities in Europe can contain many social layers that are often independent of scriptural texts; such that the appellation of "Muslim" can be appropriated without any unanimity on Islamic matters. This point is understudied, and as a consequence the dynamic features of Muslims' leadership in Europe remain unexplored. Yet it cannot be pursued by taking the route identified by Amartra Sen (2006: 75), who thinks it a mere "confusion between the plural identities of Muslims and their Islamic identity" which has bolstered "the voice of religious authorities while downgrading the importance of non-religious institutions and movements" (ibid. 77). The research question is in fact much more complicated because it requires us to examine the relationship between 1) how Muslims organise themselves or do not organise themselves, 2) what this tells us about self-definitions of "Muslim" in Europe, and 3) whether there is a European mould for the incorporation of Muslim organisations? Beginning with the first and second questions, there are, according to Neilsen (2004: 121), three main forms of Muslim organisation which have developed among Muslim minorities in Western Europe: (A) groups which arose from local communities in terms of service provision and anti-discrimination; (B) groups set up as extensions of organisations or movements from their country of origin; (C) groups set up by governments or government related agencies or to engage with them and national civil society. During the 1990s the second (B) of Neilsen's forms began to merge with the first (A), before giving way to the third (C). These were often modelled on corporatist organisations created by other, especially Jewish, faith groups e.g., the Muslim Council of Britain (MCB) and the Zentralrat de Muslime in Deauchsland (ZMD) which both draw upon the precedents of Jewish bodies and organisations. Meanwhile the Conseil Francais du Culte Musulman draws upon the Consitoire for Jews. Each Muslim organisation has thus been framed within European agendas of democratic participation, and stakeholder representation and consultation, rather than as clerical or religious bodies per se. Of course, as already discussed, Muslim minorities arrived within social contexts of reception configured by established traditions, and social scientists have illuminated the contingent ways in which European states have developed specific modes of dealing with religious difference. This leads us to the third question: exploring whether there is a European mould for the institutionalisation of Islam (cf Bader, 2007; Fetzer \& Soper, 2005; Googy, 2004; Benthall, 2003). While embryonic, Muslims-state engagement points to a re-formulation of church-state relations, indeed in 2003 the European Union discussed how to build bridges be- tween faith communities, and especially how to integrate faithbased representative bodies in wider frameworks of governance. Developments in Muslims-state engagement are therefore qualitatively novel and potentially profound, for they engage with all the questions of legitimacy - who speaks for Muslims: do they need to be "Islamic" to be "Muslim" leaders? How are they shaped by as well as shaping citizenship relations in the public domain? What are the similarities and differences both within and between different national approaches? These are just some of the pressing questions in need of investigation if we are to advance our understanding on this topic.

\section{REFERENCES}

Allen, C., \& Nielsen, J. S. (2002). Summary report on Islamophobia in the EU15 after 11 September 2001. Vienna: European Monitoring Centre for Racism and Xenophobia

Alsayyad, N., \& Castells, M. (1997). Muslim Europe or Euro-Islam. Politics, culture and citizenship in the age of globalization. Lexington: Lexington Books.

Anderson, J. (2003). New media, new publics: Reconfiguring the public sphere of Islam. Social Research, 70, 887-906.

Bader, V. (2007). The governance of Islam in Europe: The perils of modelling. Journal of Ethnic and Migration Studies, 33, 871-886. http://dx.doi.org/10.1080/13691830701432723

Banting, K., \& Kymlicka, W. (2006). Multiculturalism and the welfare state: Recognition and redistribution in contemporary democracies. Oxford: Oxford University Press. http://dx.doi.org/10.1093/acprof:oso/9780199289172.001.0001

Benthall, J. (2003). Islam in Europe. Oxford: Polity.

Bleich, E. (2009). State responses to "Muslim" violence: A comparison of six west European countries. Journal of Ethnic and Migration Studies, 35, 361-379. http://dx.doi.org/10.1080/13691830802704517

Body-Gendrot, S., \& Martiniello, M. (2000). Minorities in European cities. The dynamics of social integration and social exclusion at the neighbourhood level. Hampshire: MacMillan Press.

Bowen, J. (2007). A view from France on the internal complexity of national models. Journal of Ethnic and Migration Studies, 33, 10031016. http://dx.doi.org/10.1080/13691830701432905

Bowen, J. R. (2006). Why the French don't like headscarves: Islam, the state and public space. Princeton and Oxford: Princeton University Press.

Brubaker, R. (2001). The return of assimilation? Changing perspectives on immigration and its sequels in France, Germany, and the United States. Ethnic and Racial Studies, 24, 531-548. http://dx.doi.org/10.1080/01419870120049770

Brubaker, R. (2012). Categories of analysis and categories of practice: A note on the study of Muslims in European countries of immigration. Ethnic and Racial Studies, 1-8.

Cesari, J. (2004). When Islam and democracy meet: Muslims in Europe and in the United States. New York: Palgrave MacMillan. http://dx.doi.org/10.1057/9781403978561

Chapman, C. (1998). Islam and the West: Conflict, co-existence or conversion? Cornwall: Paternoster Press.

Commission on the Future of Multi-Ethnic Britain (CMEB) (2000). The Future of Multi-Ethnic Britain. London: Profile Books.

Etienne, B. (1989). La France et l'Islam. Paris: Hachette.

Faas, D. (2010). Negotiating political identities: Multiethnic schools and youth in Europe. Farnham: Ashgate.

Favell, A. (1998). Philosophies of integration: Immigration and the idea of citizenship in France and Britain. Basingstoke \& New York: Palgrave.

Fetzer, J., \& Soper, C. (2005). Muslims and the State in Britain, France, and Germany. Cambridge: Cambridge University Press.

Fraser, N. (1992). Rethinking the public sphere: A contribution to the critique of actually existing democracies. In C. Calhoun (Ed.), $\mathrm{Ha}$ bermas and the public sphere. Cambridge, MA: MIT Press.

Gest, J. (2010). Apart: Alienated and engaged Muslims in the West. London: Hurst Publishers.. 
Goody, J. (2003). Islam in Europe. Oxford, MA: Polity.

Hirschman, C. (2004). The role of religion in the origins and adaptation of immigrant groups in the United States. International Migration Review, 38, 1206-1233.

http://dx.doi.org/10.1111/j.1747-7379.2004.tb00233.x

Hunter, S. (2010). Europe's Muslim minority: The challenge of integration. Orient II, 15-22.

Jacobs, D., \& Rea, A. (2007). The end of national models? Integration courses and citizenship trajectories in Europe. International Journal on Multicultural Societies, 9, 264-283.

Joppke, C. (2004). The retreat of multiculturalism in the liberal state: Theory and policy. The British Journal of Sociology, 55, 237-257. http://dx.doi.org/10.1111/j.1468-4446.2004.00017.x

Klausen, J. (2005). The Islamic challenge: Politics and religion in Western Europe. Oxford: Oxford University Press.

Koopmans, R., \& Statham, P. (1999). Challenging the liberal nation -State? Postnationalism, multiculturalism, and the collective claims making of migrants and ethnic minorities in Britain and Germany. American Journal of Sociology, 105, 652-696.

http://dx.doi.org/10.1086/210357

Laurence, J., \& Vaïsse, J. (2006). Integrating Islam: Political and religious challenges in contemporary France. Washington: Brookings Institution.

Levey, G. B. (2009). Secularism and religion in a multicultural age. In G. B. Levey, \& T. Modood (Eds.), Secularism, religion and multicultural citizenship. Cambridge: Cambridge University Press.

Lewis, B., \& Schnapper, D. (1994). Muslims in Europe. London: Pinter Publishers.

Mandaville, R. (2001). Transnational Muslim politics. London and New York: Routledge. http://dx.doi.org/10.4324/9780203453155

Mandaville, R. (2009). Muslim transnational identity and state responses in Europe and the UK after 9/11: Political community, ideology and authority. Journal of Ethnic and Migration Studies, 35, 491-506. http://dx.doi.org/10.1080/13691830802704681

Maussen, M. (2007). The governance of islam in Europe: A state of art report. Amsterdam: IMESCO Working Paper No. 16.

Meer, N. (2013). Racialization and religion. Ethnic and Racial Studies, 36, 385-515. http://dx.doi.org/10.1080/01419870.2013.734392

Meer, N. (2012). Misrecognising Muslim consciousness in Europe. Ethnicities, 12, 178-197. http://dx.doi.org/10.1177/1468796811431295

Meer, N. (2010). Citizenship, identity \& the politics of multiculturalism. Palgrave. http://dx.doi.org/10.1057/9780230281202

Meer, N., Dwyer, C., \& Modood, T. (2010) Embodying nationhood? Conceptions of British national identity, citizenship and gender in the “veil affair". The Sociological Review, 58, 84-111. http://dx.doi.org/10.1111/j.1467-954X.2009.01877.x

Modood, T., \& Ahmad, F. (2007). British Muslim perspectives on multiculturalism. Theory, Culture \& Society, 24, 187-213. http://dx.doi.org/10.1177/0263276407075005

Modood, T., Berthoud, R., Lakey, J., Nazroo, J., Smith, P., Virdee, S., \& Beishon, S. (1997). Ethnic minorities in Britain: Diversity and disadvantage: The fourth national survey of ethnic minorities, policy studies institute.

Modood, T. (2009). Ethnicity and Religion. In M. Flinders, A. Gamble, C. Hay, \& M. Kenny (Eds.), The oxford handbook of British politics. Oxford University Press.

http://dx.doi.org/10.1093/oxfordhb/9780199230952.003.0026

Modood, T. (2007). Multiculturalism: A civic idea. Cambridge: Polity.

Modood, T. (1994). Political blackness and British Asians. Sociology, 28, 859-876. http://dx.doi.org/10.1177/0038038594028004004

Modood, T. (1988). "Black", racial equality and asian identity. New Community, 14, 3.

Modood, T., Triandafyllidou, A., \& Zapata-Barrero, R. (2006). Multiculturalism, Muslims and citizenship: A European approach. Abingdon \& New York: Routledge.

Nielsen, J. (1984). Muslim immigration and settlement in Britain. Research Papers: Muslims in Europe, no. 21, CSIC, Birmingham.

Nielsen, J. S. (1992). Muslims in Western Europe. Edinburgh: Edinburgh University Press.
Nielsen, J. S. (1999). Towards a European Islam, Migration, Minorities and Citizenship. Houndmills, Basingstoke: MacMillan. http://dx.doi.org/10.1057/9780230379626

Nielsen, J. S. (2004). Muslims in Western Europe (3rd ed.). Edinburgh: Edinburgh University Press.

Open Society Institute (2010). At home in Europe: A report on $11 \mathrm{EU}$ cities. London: Open Society Institute.

O’Toole, T., Modood, T., DeHanas, D., Meer, N., \& Jones, S. (2013). Taking part: Muslim participation in contemporary governance. Bristol: CSEC.

PGAP (PEW GLOBAL ATTITUDES PROJECT) (2008). Unfavorable views of Jews and Muslims on the increase in Europe. Washington DC: Pew Research Center. Summary. http://www.pewglobal.org/subjects/islamophobia/

Pew Forum on Religion and Public Life (2010). Muslim networks and movements in Western Europe. Washington: Pew Research Centre. http://www.pewforum.org/uploadedFiles/Topics/Religious_Affiliatio n/Muslim/Muslim-networks-full-report.pdf

Ramadan, T. (1999). To be a European Muslim. Leicester: Islamic Foundation.

Ramadan, T. (2004). Western Muslims and the future of Islam. New York: Oxford University Press.

Roy, O. (2004). Globalised Islam: The search for a New Umma. London: Hurst.

Safi, O. (2004). Introduction: “The Times They Are a-changing”. In O. Safi (Ed.), Progressive Muslims on Justice, Gender and Pluralism (pp. 147-162). Oxford: Oneworld.

Schirin, A.-M. (2007). Euro-Islam, Islam in Europe, or Europe revised through Islam? Versions of Muslim Solidarity within European borders. In Nathalie Karagiannis (Hg.). European Solidarity and Solidarity beyond Europe (pp. 186-213). Liverpool: Liverpool University Press.

Schönwälder, K. (2001). Einwanderung und ethnische Pluralität. Politische Entscheidungen und öffentliche Debatten in Großbritannien und der Bundesrepublik von den 1950er bis zu den 1970er Jahren. Essen: Klartext Verlag.

Sen, A. (2006). Identity and violence: The illusion of destiny. New York: W. W. Norton.

Simon, P., \& Piché, V. (2012). Accounting for ethnic and racial diversity: The challenge of enumeration. Ethnic and Racial Studies, 35, 1357-1365.

Soysal, Y. (1994). Limits of Citizenship: Migrants and Postnational Membership in Europe. Chicago: University of Chicago Press.

Tibi, B. (1998). Europa ohne Identita"t, Die Krise der multikulturellen Gesellschaft. Munich: Bertelsmann.

Tibi, B. (2008). Political islam, world politics and Europe: Democratic peace and euro-islam versus global jihad. Chippenham: Routledge.

Triandafyllidou, A., Modood, T., \& Meer, N. (2011). European multiculturalism(s): Cultural, religious and ethnic challenges. Edinburgh: Edinburgh University Press.

Triandafyllidou, A. Muslims in 21st Century Europe: Structural and cultural perspectives. Routledge.

Werbner, P. (1994). Diaspora and millennium: British Pakistani globallocal fabulations of the Gulf War.In S. Ahmed, \& H. Donnan (Eds.), Islam, globalization and postmodernity (pp. 209-231). London: Routledge.

Yildiz, A. A., \& Verkuyten, M. (2012). Conceptualising Euro-Islam: Managing the societal demand for religious reform. Identities, 19, 360376. http://dx.doi.org/10.1080/1070289X.2012.713863

Voas, D., \& Ling, R. (2010). Religion in Britain and the United States. In A. Park et al. (Eds.), British Social Attitudes: The 26th Report (pp. 65-86). London: SAGE. http://dx.doi.org/10.4135/9781446212073.n4

Zolberg, A., \& Woon, L. (1999). Why Islam is like Spanish: Cultural Incorporation in Europe and the United States. Politics \& Society, 27, 5-38. http://dx.doi.org/10.1177/0032329299027001002

Zick, A., Kupper, B., \& Hovermann, A. (2011). Intolerance, prejudice and discrimination. Berlin: Forum Berlin. http://library.fes.de/pdf-files/do/07908-20110311.pdf 